\title{
RESPIRATORY SYMPTOMS AND SMOKING HABITS OF SENIOR INDUSTRIAL STAFF
}

\author{
BY \\ SUSAN H. MEADOWS, C. H. WOOD, and R. S. F. SCHILLING \\ From the Department of Occupational Health and Applied Physiology, \\ London School of Hygiene and Tropical Medicine
}

(RECEIVED FOR PUBLICATION JULY 23, 1964)

\begin{abstract}
The prevalence of respiratory symptoms and the smoking habits of 224 industrial 'executives' aged 30 to 69 years in Social Classes I and II were ascertained by means of the Medical Research Council's questionnaire on respiratory symptoms; $31 \%$ had persistent cough, $25 \%$ had persistent phlegm, and $21 \%$ were short of breath on hurrying or going up a hill; $9 \%$ had had one or more chest illnesses in the past three years lasting for about a week, and $4 \%$ had 'chronic bronchitis'-defined as persistent phlegm and one or more chest illnesses in the past three years; $67 \%$ were smokers, $21 \%$ smoking more than 25 cigarettes (or equivalent tobacco) per day; another $20 \%$ had stopped smoking. The prevalence of cough, phlegm, and breathlessness was closely related to smoking habit.

Data for those aged 40 to 59 years are compared with that obtained from London Transport Board workers and a sample of the population studied by the College of General Practitioners. The latter was further analysed and suggests that the prevalence of cough and phlegm is more closely related to the amount smoked than to social class. The prevalence of chest illness is probably more closely related to social class and less to the amount smoked. It is suggested that, although smoking may initiate irritative respiratory symptoms, the precursors of bronchitis, additional factors are important in causing progression to disabling or fatal chronic bronchitis.
\end{abstract}

The association between bronchitis mortality and social class in males has been well established by the Registrar General of England and Wales. In the most recently published figures there is a steep gradient in the Standardized Mortality Ratio from 34 in Social Class I to 171 in Social Class V (Registrar General, 1958). Evidence of a similar association between bronchitis morbidity and social class is less obvious. Logan (1960), in a study of morbidity statistics from general practices in England and Wales, found for bronchitis a social class gradient in Standardized Patient Consulting Ratios which was similar to but less steep than the mortality gradient. In a study of men in the seventh decade, Brown, McKeown, and Whitfield (1957) showed a rising incidence of bronchitis from Social Classes I and II to Social Class V, but only among smokers.

Other studies of patients in hospital and general practice have failed to find any association between bronchitis and social class (Oswald, Harold, and Martin, 1953; Fry, 1954).

Community surveys of respiratory symptoms which indicate the prevalence of the early stages of chronic bronchitis have been undertaken in populations consisting mostly of skilled manual workers who belong to Social Class III, and of partially skilled and unskilled workers (Social Classes IV and V) (Higgins, Oldham, Cochrane, and Gilson, 1956). They have seldom included sufficient numbers from professional and managerial workers (Social Classes I and II) to allow any reliable comparison between all classes.

In an attempt to get more information about the prevalence of early bronchitis in Social Classes I and II a survey of respiratory symptoms was undertaken among the senior staff of various industrial concerns in the London area. Particular attention was paid to smoking habits and their relation to symptoms, since cigarette smoking must now be accepted as a major factor in the aetiology of chronic bronchitis (British Medical Journal, 1963; Royal College of Physicians, 1962; Scottish Home and Health Department, 1963).

The Medical Research Council's questionnaire 
on respiratory symptoms (Medical Research Council Committee on the Aetiology of Chronic Bronchitis, 1960) was used for the survey. The population studied was randomly selected from men participating in a scheme for routine health supervision (Meadows, 1964). Two hundred and twenty-eight (97\% of the sample) were seen and the results are presented for the 224 aged 30 to 69 years; of these, $34 \%$ were directors, $46 \%$ specialists, and $21 \%$ supervisors. For convenience they are all referred to as executives. Similar data for respiratory symptoms and smoking habits are given for men from the same social classes recently surveyed by the College of General Practitioners (1961). The data from this latter survey have been further analysed to compare the relation between smoking and respiratory symptoms for all five social classes.

\section{Results}

Prevalences of cough, phlegm, breathlessness, chest illness, and 'chronic bronchitis' for the male executives are shown in Table 1.

Although there is a general trend towards an increase in symptoms and chest illness with age, the age group 40-49 has a lower prevalence of all symptoms, except breathlessness, than the 30-39 age group. The reason for this is not clear. It was not due to differences in smoking habits.

In the survey undertaken by the College of General Practitioners (1961) a similar but not identical questionnaire was used, and comparisons are therefore limited to certain questions. Out of 787 men seen, the 104 aged 40 to 59 years from Social Classes I and II living in urban areas have been selected for comparison (Table 2).

The prevalence of morning cough, morning phlegm, and chest illness is very similar for the two populations in the 50-59 age group. For those aged 40 to 49 years the executives have a much lower
TABLE 2

COMPARISON OF RESPIRATORY SYMPTOMS IN THE TWO MALE POPULATIONS (COLLEGE OF GENERAL PRACTITIONERS' SURVEY AND EXECUTIVES) AGED 40 TO 59 YEARS DRAWN FROM SOCIAL CLASSES I AND II

\begin{tabular}{l|l|c|c|c|c}
\hline $\begin{array}{c}\text { Age } \\
\text { Group }\end{array}$ & Population & No. & \multicolumn{3}{|c}{ Percentage With } \\
\cline { 5 - 6 } & $\begin{array}{c}\text { Morning } \\
\text { Cough* }\end{array}$ & $\begin{array}{c}\text { Morning } \\
\text { Phlegm } \dagger\end{array}$ & $\begin{array}{c}\text { Chest } \\
\text { Illness } \ddagger\end{array}$ \\
\hline $40-49$ & C.G.P. Survey & 48 & 40 & 40 & 10 \\
& Executives & 97 & 24 & 17 & 4 \\
\hline $50-59$ & C.G.P. Survey & 56 & 34 & 30 & 9 \\
& Executives & 65 & 37 & 28 & 11 \\
\hline
\end{tabular}

*Those who cough in the morning in winter (M.R.C. positive to questions 1 and 5 ; C.G.P. positive to question 2).

†Those who produce phlegm in the morning in winter (M.R.C. positive to questions 6 and $10 ;$ C.G.P. positive to question 7).

fOne or more chest illnesses in past three years lasting for at least a week, with increased phlegm.

prevalence of symptoms and illness than the men in the College of General Practitioners survey who compare unfavourably with the older men seen in the same survey.

There was no major difference in the smoking habits of those seen in the two surveys; both contained similar proportions of cigarette smokers. As a group, the executives smoked rather more heavily and had more non-smokers and fewer ex-smokers. A comparison of those between the ages of 40 and 59 is given in Table 3.

Data on the prevalence of respiratory symptoms in occupational groups obtained with the Medical Research Council questionnaire are limited. Recently a survey of London Transport Board (L.T.B.) clerical and maintenance workers who belong to Social Classes III and IV has been undertaken (Fletcher, 1964). Provisional figures indicate that the executives have a lower prevalence and severity of respiratory symptoms than the L.T.B. workers in the age group 40-49, but not in the older age group 50-59 (Table 4).

TABLE 1

PREVALENCE OF SYMPTOMS BY AGE IN MALE EXECUTIVES

\begin{tabular}{|c|c|c|c|c|c|c|c|c|c|c|c|}
\hline \multirow{2}{*}{$\begin{array}{c}\text { Age } \\
\text { Group }\end{array}$} & \multirow{2}{*}{ No. } & \multicolumn{2}{|c|}{ Cough* } & \multicolumn{2}{|c|}{ Phlegm $†$} & \multicolumn{2}{|c|}{ Breathlessness $\ddagger$} & \multicolumn{2}{|c|}{$\begin{array}{l}\text { Chest } \\
\text { Illness § }\end{array}$} & \multicolumn{2}{|c|}{$\begin{array}{c}\text { 'Chronic } \\
\text { Bronchitis'\|l }\end{array}$} \\
\hline & & No. & $\%$ & No. & $\%$ & No. & $\%$ & No. & $\%$ & No. & $\%$ \\
\hline $\begin{array}{l}30-39 \\
40-49 \\
50-59 \\
60-69\end{array}$ & $\begin{array}{l}40 \\
97 \\
65 \\
22\end{array}$ & $\begin{array}{r}11 \\
25 \\
25 \\
8\end{array}$ & $\begin{array}{l}28 \\
26 \\
39 \\
36\end{array}$ & $\begin{array}{r}10 \\
17 \\
20 \\
8\end{array}$ & $\begin{array}{l}25 \\
18 \\
31 \\
36\end{array}$ & $\begin{array}{r}5 \\
17 \\
15 \\
10\end{array}$ & $\begin{array}{l}13 \\
18 \\
23 \\
46\end{array}$ & $\begin{array}{l}4 \\
4 \\
7 \\
4\end{array}$ & $\begin{array}{r}10 \\
4 \\
11 \\
18\end{array}$ & $\begin{array}{l}2 \\
1 \\
5 \\
2\end{array}$ & $\begin{array}{l}5 \\
1 \\
8 \\
9\end{array}$ \\
\hline Total & 224 & 69 & 31 & 55 & 25 & 47 & 21 & 19 & 9 & 10 & 4 \\
\hline
\end{tabular}

* Those who cough regularly in winter, irrespective of the time of day (positive to questions 1 and/or 3 and 5).

$†$ Those who produce phlegm regularly in winter, irrespective of the time of day (positive to questions 6 and/or 8, and 10).

$\ddagger$ Those troubled by shortness of breath on hurrying or going uphill and over, i.e., grade 2 and over (positive to questions 14a and over). §One or more chest illnesses in past three years lasting for at least a week, with increased phlegm.

\|Regular production of phlegm and one or more chest illnesses in the past three years lasting for at least a week, with increased phlegm. 
TABLE 3

COMPARISON OF SMOKING HABITS IN THE TWO MALE POPULATIONS (C.G.P. SURVEY AND EXECUTIVES) AGED 40 TO 59 YEARS DRAWN FROM SOCIAL CLASSES I AND II

\begin{tabular}{|c|c|c|c|c|c|c|c|c|}
\hline \multirow{3}{*}{ Population } & \multicolumn{8}{|c|}{ Percentage } \\
\hline & \multicolumn{3}{|c|}{$\begin{array}{l}\text { Smokers } \\
\text { (quantity) }\end{array}$} & \multirow{2}{*}{$\begin{array}{l}\text { Non- } \\
\text { smokers }\end{array}$} & \multirow{2}{*}{$\begin{array}{c}\text { Ex- } \\
\text { smokers }\end{array}$} & \multicolumn{3}{|c|}{$\begin{array}{c}\text { Smokers } \\
\text { (type) }\end{array}$} \\
\hline & $\begin{array}{l}1 \text { to } 14 \\
\text { g./day }\end{array}$ & $\begin{array}{l}15 \text { to } 24 \\
\text { g./day }\end{array}$ & $\begin{array}{l}25 \text { or more } \\
\text { g./day }\end{array}$ & & & 'Mixed' & $\begin{array}{c}\text { Pipe or } \\
\text { Cigar }\end{array}$ & Cigarette \\
\hline $\begin{array}{l}\text { Executives } \\
\text { C.G.P. }\end{array}$ & $\begin{array}{l}23 \\
34\end{array}$ & $\begin{array}{l}27 \\
19\end{array}$ & $\begin{array}{l}20 \\
14\end{array}$ & $\begin{array}{r}12 \\
9\end{array}$ & $\begin{array}{l}19 \\
25\end{array}$ & $\begin{array}{r}11 \\
8\end{array}$ & $\begin{array}{l}12 \\
12\end{array}$ & $\begin{array}{l}47 \\
47\end{array}$ \\
\hline
\end{tabular}

TABLE 4

COMPARISON OF PREVALENCE OF PHLEGM, CHEST ILLNESS, AND 'CHRONIC BRONCHITIS' IN MALE LONDON TRANSPORT BOARD WORKERS AND EXECUTIVES

\begin{tabular}{|c|c|c|c|c|c|}
\hline \multirow{2}{*}{$\begin{array}{l}\text { Age } \\
\text { Group }\end{array}$} & \multirow{2}{*}{ Population } & \multirow{2}{*}{ No. } & \multicolumn{3}{|c|}{ Percentage With } \\
\hline & & & Phlegm & $\begin{array}{l}\text { Chest } \\
\text { Illness }\end{array}$ & $\begin{array}{l}\text { 'Chronic } \\
\text { Bronchitis' }\end{array}$ \\
\hline $40-49$ & $\begin{array}{l}\text { L.T.B. } \\
\text { Executives }\end{array}$ & $\begin{array}{l}433^{*} \\
97\end{array}$ & $\begin{array}{l}27 \\
18\end{array}$ & $\begin{array}{l}9 \\
4\end{array}$ & $\begin{array}{l}5 \\
1\end{array}$ \\
\hline $50-59$ & $\begin{array}{l}\text { L.T.B. } \\
\text { Executives }\end{array}$ & $\begin{array}{l}485^{*} \\
65\end{array}$ & $\begin{array}{l}31 \\
31\end{array}$ & $\begin{array}{l}10 \\
11\end{array}$ & $\begin{array}{l}6 \\
8\end{array}$ \\
\hline
\end{tabular}

*This was a stratified sample using a variable sampling fraction; 918 males were seen but the prevalence figures have been adjusted to make them representative of the total population from which the sample was drawn.

Smoking and Symptoms Among Executives.-In examining the relation of symptoms to smoking among the executives (Table 5), the non- and exsmokers are kept separate although the numbers are small because they show considerable differences in prevalence of symptoms.

There is a definite trend of increasing symptoms, chest illness, and bronchitis from non-smokers through the grades of smokers. The differences between smokers and non-smokers are statistically significant for cough and phlegm and breathlessness $(P<0.01)$. The differences between those smoking over $15 \mathrm{~g}$. a day and under $15 \mathrm{~g}$. a day are also statistically significant for cough and phlegm. Ex-smokers have more symptoms than non-smokers but less than moderate or heavy smokers; they have the highest prevalence of chest illness of any group. The relation between smoking and symptoms might arise simply because the older workers who are expected to have more symptoms also smoked more than the younger workers. Further analysis of the data revealed that this is not the case.

Social Class and Smoking.-Data were extracted from the College of General Practitioners' study in order to consider further the effect of smoking on respiratory symptoms for the different social classes. Considering all social classes together, there is a marked increase in prevalence of morning phlegm from $6 \%$ among the non-smokers to $55 \%$ among the heavy smokers, with a consistent increase for the amount smoked in each social class except $\mathrm{V}$ (Table 6). The ex-smokers have a prevalence between that of the non-smokers and that of the light smokers. There is a less regular relation between prevalence of morning phlegm and social class. Considering all smoking groups together the prevalence is $35 \%$ in Social Classes I and II and $54 \%$ in Social Class V. Similar trends are observed when morning cough is examined in relation to smoking habit and social class.

None of the non-smokers in any social class reported a chest illness in the past three years. Among the smokers there is no clear relation between the amount smoked and the prevalence of

TABLE 5

PREVALENCE OF SYMPTOMS ACCORDING TO SMOKING HABIT IN 198 EXECUTIVES*

\begin{tabular}{|c|c|c|c|c|c|c|c|c|c|c|}
\hline \multirow{2}{*}{ Smoking Habit } & \multirow{2}{*}{\multicolumn{2}{|c|}{ Non-smokers }} & \multicolumn{6}{|c|}{ Cigarette and 'Mixed' Smokers } & \multirow{2}{*}{\multicolumn{2}{|c|}{ Ex-smokers }} \\
\hline & & & \multicolumn{2}{|c|}{1 to $14 \mathrm{~g} . /$ day } & \multicolumn{2}{|c|}{15 to 24 g. $/$ day } & \multicolumn{2}{|c|}{25 or more g./day } & & \\
\hline Number & \multicolumn{2}{|c|}{28} & \multicolumn{2}{|c|}{26} & \multicolumn{2}{|c|}{53} & \multicolumn{2}{|c|}{45} & \multicolumn{2}{|c|}{46} \\
\hline $\begin{array}{l}\text { Those with: } \\
\text { Cough } \\
\text { Phlegm } \\
\text { Breathlessness } \\
\text { Chest illness } \\
\text { 'Chronic bronchitis' }\end{array}$ & $\begin{array}{c}\text { (no.) } \\
1 \\
2 \\
1 \\
1 \\
0\end{array}$ & $\begin{array}{c}(\%) \\
4 \\
7 \\
4 \\
4 \\
0\end{array}$ & $\begin{array}{c}\text { (no.) } \\
1 \\
4 \\
4 \\
2 \\
1\end{array}$ & $\begin{array}{c}(\%) \\
4 \\
15 \\
15 \\
8 \\
4\end{array}$ & $\begin{array}{c}\text { (no.) } \\
25 \\
20 \\
15 \\
4 \\
2\end{array}$ & $\begin{array}{c}(\%) \\
47 \\
38 \\
28 \\
8 \\
4\end{array}$ & $\begin{array}{r}\text { (no.) } \\
26 \\
18 \\
14 \\
4 \\
4\end{array}$ & $\begin{array}{c}(\%) \\
58 \\
40 \\
31 \\
9 \\
9\end{array}$ & $\begin{array}{c}\text { (no.) } \\
9 \\
7 \\
9 \\
6 \\
3\end{array}$ & $\begin{array}{c}(\%) \\
20 \\
15 \\
20 \\
13 \\
7\end{array}$ \\
\hline
\end{tabular}

*Those smoking only pipes or cigars have been omitted because the numbers are small.

7 
TABLE 6

STUDY OF 507 MALES AGED 40 TO 59 BY THE COLLEGE OF GENERAL PRACTITIONERS: PERCENTAGE WITH MORNING PHLEGM ACCORDING TO SOCIAL CLASS AND SMOKING HABIT

\begin{tabular}{|c|c|c|c|c|c|c|c|}
\hline & & \multirow{2}{*}{ Non-smokers } & \multicolumn{3}{|c|}{ Smokers } & \multirow{2}{*}{ Ex-smokers } & \multirow{2}{*}{ All } \\
\hline & & & 1 to $14 \mathrm{~g} / \mathrm{day}$ & 15 to $24 \mathrm{~g} . / \mathrm{day}$ & 25 or more g./day & & \\
\hline Social Class & No. & 35 & 199 & 121 & 64 & 88 & 507 \\
\hline $\begin{array}{l}\text { I and II } \\
\text { III } \\
\text { IV } \\
\text { V }\end{array}$ & $\begin{array}{r}104 \\
272 \\
66 \\
65\end{array}$ & $\begin{array}{l}\% \\
0 \\
9 \\
0 \\
0\end{array}$ & $\begin{array}{l}\% \\
31 \\
40 \\
47 \\
57\end{array}$ & $\begin{array}{l}\% \\
55 \\
46 \\
63 \\
61\end{array}$ & $\begin{array}{l}\% \\
57 \\
53 \\
67 \\
50\end{array}$ & $\begin{array}{l}\% \\
23 \\
29 \\
10 \\
46\end{array}$ & $\begin{array}{l}\% \\
35 \\
39 \\
46 \\
54\end{array}$ \\
\hline All & 507 & 6 & 42 & 52 & 55 & 27 & 41 \\
\hline
\end{tabular}

TABLE 7

STUDY OF 507 MALES AGED 40 TO 59 BY THE COLLEGE OF GENERAL PRACTITIONERS: PERCENTAGE WITH PAST CHEST ILLNESS* ACCORDING TO SOCIAL CLASS AND SMOKING HABIT

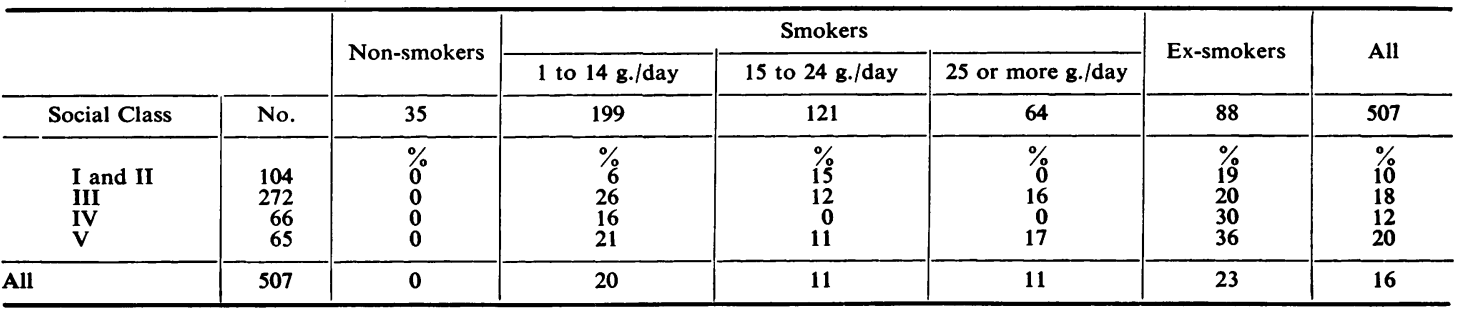

* One or more chest illnesses in the past three years lasting at least a week, with increased phlegm.

chest illness. The ex-smokers have a generally higher rate than the others (Table 7). There is, however, rather more chest illness among Social Classes III, IV, and V than among Social Classes I and II.

\section{Discussion}

There are difficulties in comparing the prevalence of respiratory symptoms between different social classes. The findings are based on answers to questions which may reflect differences in the threshold of perception; it is possible that cough and phlegm regarded as 'normal' and overlooked by manual workers may be recorded as abnormal by executive staff. Similarly, an increase in phlegm may be regarded differently and this will be reflected in the number of chest illnesses accompanied by an increase in phlegm that are recorded.

Thus the comparisons made between social classes in this paper are liable to error. Nevertheless the general conclusions are that respiratory symptoms and illness vary with both the amount smoked and social class.

The most striking and probably the most reliable result was that of increasing cough, phlegm, and breathlessness in the executives according to the amount they smoked. A similar trend has been found by Fletcher, Elmes, Fairbairn, and Wood (1959) among postmen (Social Class III) and has been demonstrated for each social class in the College of General Practitioners' study.

Evidence from this latter source suggests that persistent cough and phlegm, the initial symptoms of bronchitis, are more closely related to the amount smoked than to social class, whereas chest illness is probably more closely related to social class and less to the amount smoked.

Thus it appears that although smoking initiates irritative respiratory symptoms, the precursors of chronic bronchitis, some other factors that are broadly associated with social class are largely responsible for progression to disabling or fatal chronic bronchitis. It is possible that chest infection, particularly if inadequately treated, or if heavy work is resumed too quickly afterwards, might be responsible for such progression. These events are more likely to occur in partially skilled and unskilled workers where standards of personal and medical care are generally lower.

We should like to thank Miss Joan Walford for help in preparing this paper; Miss Sheila Farrow and Miss Elizabeth Farrow for computing assistance; the Respiratory Diseases Study Group of the College of General 
Practitioners who gave access to their original data; and Dr. C. M. Fletcher who made available unpublished figures on London Transport Board workers.

We are also indebted to the firms and their senior staff who co-operated so willingly in this enquiry, to Lord Taylor, Miss Nancy Savill, and the staff of the Harlow Industrial Health Service and the Personnel Department of Richard Costain Ltd.

\section{REFERENCES}

British Medical Journal (1963). 2, 1144.

Brown, R. G., McKeown, T., and Whitfield, A. G. E. (1957). Brit. prev. soc. Med. $2,162$.

College of General Practitioners (1961). Brit. med. J., 2, 973.
Fletcher, C. M. (1964). Personal communication.

Elmes, P. C., Fairbairn, A. S., and Wood, C. H. (1959). Brit. med. J., 2, 257

Fry, J. (1954). Ibid., 1, 190. . (1956) T. Obid., 2,904

Logan, W. P. D. (1960). Morbidity Statistics from General Practice, Vol. II (Occupation). General Register Office Studies on Medical and Population Subjects, No. 14. London, H.M.S.O.

Meadows, S. (1964). Brit. J. industr. Med., 21, 226.

Medical Research Council Committee on the Aetiology of Chronic Bronchitis (1960). Brit. med. J., 2, 1665.

Oswald, N. C. Harold, J. T., and Martin, W. J. (1953). Lancet, 2, 639.

Registrar General (1958). Decennial Supplement, England and Wales 1951, Occupational Mortality, Part II, 2. London, H.M.S.O.

Royal College of Physicians (1962). Smoking and Health. London, Pitman.

Scottish Home and Health Department (1963). Report of a SubCommittee of the Standing Medical Advisory Committee London, H.M.S.O. 